\title{
Impact of Washback on ESL Students' Performance at Secondary Level
}

\author{
Muhammad Arfan Lodhi ${ }^{1}$, Irum Robab ${ }^{2}$, Sumera Mukhtar ${ }^{3}$, Hifza Farman ${ }^{4} \&$ Sana Farrukh $^{5}$ \\ ${ }^{1}$ Higher Education Department Collegiate Wing, Punjab, Pakistan \\ ${ }^{2}$ The Islamia University of Bahawalpur, Pakistan \\ ${ }^{3}$ The University of Lahore Pakpattan Campus, Pakistan \\ ${ }^{4}$ NCBA\&E University Rahim Yar Khan Campus, Pakistan \\ ${ }^{5}$ NCBA\&E Lahore, Pakistan \\ Correspondence: Muhammad Arfan Lodhi, Lecturer, Higher Education Department Collegiate Wing, Punjab \\ Pakistan. E-mail: samaritan_as@hotmail.com
}

Received: July 20, 2018 Accepted: August 15, 2018 Online Published: September 1, 2018

doi:10.5539/ijel.v8n6p227 URL: https://doi.org/10.5539/ijel.v8n6p227

\begin{abstract}
This descriptive study explores the impact of washback on ESL students' performance at secondary level. In this study, the term "washback" refers to the test effect on content of curriculum, learning English, teaching and the activities conducted in classroom. The factors other than the test itself may affect positive washback; lack of positive washback does not make test invalid whereas the negative washback effect occurs when there is lack of construct validity of test. Test design and validity plays vital role in achieving positive washback (Messick, 1996). The study aims to investigate the effects of positive washback and benefits in learning and teaching processes in ESL classrooms, while negative washback effects are destructive and can be a hindrance in achieving the goals in ESL classrooms. Recent research is descriptive in nature and survey based method was adopted for this study. 50 teachers were selected by using purposive sampling technique and 100 students were selected by using simple random sampling technique. Three tools were used for this study including: Questionnaire, Test and Observation checklist. The findings of the study exhibit that negative washback effect has its influence on tests, learning and teaching. The study concludes with a realization of the fact that language pedagogy is affected by washback. However, it is claimed by majority of the teachers that washback affects the selection of teaching methods because exams stress brings pressure and it becomes necessary for English teachers to develop linguistic competence in their students. For future researches it is recommended that other studies should be made in order to find out the impact of washback on the strategies adopted by learners while learning second language.
\end{abstract}

Keywords: washback effect, ESL teaching, English teaching strategies, language learning performance

\section{Introduction}

\subsection{Introduction}

Tests affect teaching and learning taken place in the classroom (Cheng, 2001). In applied linguistics this effect is known as washback whereas in edification phraseology it is named as backwash. Studies show that washback is not an easy process and its nature is complicated particularly in learning and teaching (Cheng, Watanabe \& Curtis, 2004). The use of test can improve or hinder teaching and learning process. Shohamy (1992) supposed test results to be fundamental for individual and curriculum because main decisions about an individual and curriculum are taken based on the obtained results. The test washback concept has been about for a prolonged time. Teachers are always been familiar of tests' effect on instructive plans, learners and teachers. Recently, researchers have been advocated to investigate the notion. Findings proposed the existence of washback phenomenon and considered it to be complex to impart itself in simple investigational designs. It is obvious that various personal and contextual factors interrelate in influencing tests' effects on classroom practices (Alderson \& Hamp-Lyons, 1996). 
Washback is frequently presented in language testing curriculum as an influential notion for test designer to ponder and for awareness of teachers in classroom too. Davies (1985) inquires whether test ought to essentially pursue the syllabus and proposes that possibly tests have to control and affect syllabus. Morrow (1986) believed that the term "washback validity" can explain the worth of the correlation of testing, teaching, and learning process as these are interrelated. He declared that examining washback validity helps the testing researchers to examine the influence of test being used. Overall education, researchers have affirmed that high-stakes testing might activate numerous unethical test preparations or encourage teachers in test preparation and control the students' test scores.

The above stated ideas about test effects, however, have rarely been practically supported in the field of language testing until Alderson \& Wall (1993) put forward their washback premises as the basis for other researchers to carry out further researches on it. To check the washback effect of tests, the areas of teaching and learning in classroom are focused by the researchers are teaching material, teaching techniques, assessment techniques, teaching style, classroom environment and teachers' attitude regarding the test. In ESL classrooms, effects of positive washback are required and beneficial in learning and teaching processes, while negative washback effects are destructive and can be a hindrance in achieving the goals. Negative effects emerge when a classroom teaching is conducted entirely based on narrowed examination purposes (Prodromou, 1995). Positive washback can be promoted by making changes in curriculum, teaching methods and techniques and by motivating the students. Students have a natural tendency to modify their learning activities in the classroom to fulfill the requirements of the tests (Buck, 1988).

This study indicates the impact of positive and negative washback on ESL students' performance, the factors affecting their performance and the extent to which a teacher can make efforts in promoting positive wash-back. It highlights the strong effect of washback on ESL students' performance. Cheng (2001) also concluded tests to be enough strong to influence teaching and learning practices. The purpose of this research is to investigate the possibility of creating positive washback by concentrating on factors in test development process and anticipating the situations most probably leading to positive wash-back in ESL students' performance.

\subsection{Research Questions}

1) What is the impact of positive washback on ESL students' performance at secondary level?

2) To what extent a negative washback can be changed into positive washback in ESL students' performance at secondary level?

3) What are the factors that affect ESL students' performance in exams?

4) What is the role of a teacher in promoting positive washback on ESL students' performance at secondary level?

\section{Review of the Related Literature}

\subsection{Washback}

The term washback refers to the effect that a test has on the way in which students are taught. It can have both positive and negative effect. According to Alderson \& Wall (1993), teaching, learning and testing are interrelated. Nowadays, English has become important mean of communication so; oral communication is the most important activity while learning ESL (Al Hosni, 2014). According to McNamara (2000), type of test can be a vital factor. He assumes that performance tests have more positive effect as compared to testing of distinct feature which frequently suppress communicative instructive methods. Furthermore, studies on the influence of the preface of outcome centered review in Australia, confirms this perspective.

Examinations are even now the main instrument of evaluation in schools, service and profession advancement. Thus, what is evaluated develops into what is worthier, which turns into what is taught (Mc Ewen, 1995). After native language learning the another language which is learned is known as second language and the second language learning practice is termed as second language acquisition (Gass \& Selinker, 2008). There are factors that affect successful second language learning (Lee, 2010). Teachers' pedagogies and methods are affected by exams and teachers need to modify their practices according to exams requirement producing a prejudgment about the curriculum (Rodrı guez, 2016). Teachers need to study particular range of educational theories that affect the classroom management, students learning styles as teachers are helpful for any investigation on washback and play important role in carrying positive and negative washback effect (Cheng, 2015).

In Pakistani culture, English language has at all the times been the language of authority and a fundamental class marker (Bashir et al., 2011). Testing is important to observe the efficacy of teaching and learning. As a result, the instructors, learners, testers, syllabus designers, strategy makers, organizations and management, all are 
influenced by testing. Pakistani teachers and students ignore the real learning and teaching and focus only on examination. Examination is merely essential in their view. Poor vocabulary, the impact of L1 and improper class atmosphere can be the factors that hinder learning English Language (Bilal et al., 2013). Although many teachers consider teaching speaking as main element of learning a language but due to less time they are unable to do so. They have to complete the whole syllabus in allocated time (Baniabdelrahman, 2013). According to Madsa (2012) learners should be provided good atmosphere in which they feel confident and take part in discussion.

The demands of evaluating learning outcomes have directed to the progress and expansion of many kinds of test formats. Language testing has conventionally taken the mode of testing a learner's knowledge regarding language, generally the knowledge testing of grammar and vocabulary. As the main purpose of teaching a language is successful learning of a language so learning outcomes must be the central concern (Mehrpour \& Vojdani, 2012). Different types of tests are used to evaluate learning outcomes and all have different purposes.

- Paper and Pencil Language Test

- Product based Test

- Performance based Test

- Process based Test

- Achievement Test

- Diagnostic Test

- Placement Test

- Cloze Test

- Discrete-Point Test

- Language Aptitude Test

- Progress Test

- Proficiency Test

2.2 Qualities of a Good Test

\subsubsection{Reliability}

A good test must be greatly reliable. This signifies that the test must provide same scores even if different test takers conduct it, many people marks in various types of the given assessment and the same test taker conducts that test at more than one divergent time. The term reliability basically signifies "stability, constancy, steadiness, and precision of test results" (McMillan, 2001). As there is remarkable inconsistency from either tester or instructor to tester/ instructor that influence learner performance, therefore reliability in developing, executing, and scoring learner attainments offers valid assessment.

\subsubsection{Validity}

Validity is not an assessment's or a test's characteristic; but it is a judgment having changeable levels of strength. So, validity is the second characteristic of a good test, which signifies whether that test is really evaluating what it declares to evaluate (Kelley, 1927). This is essential for test takers as they do not intend to make declarations regarding what thing a learner is capable of doing or not depending on a test while the test is in fact evaluating something else. Usually validity is determined logically even though various kinds of validity might exploit correlation coefficients.

\subsubsection{Practicality}

Although practicality is one of the most essential traits of tests, it is also a testing's limiting factor. In some situations after the test taker has already verified the test to be the most valid, the test's format is required to be reconsidered due to practicality issues. A test is affective if it is practical. A test is said to be practical when it limits time and budget, and also engross clear interpretation, administration and scoring (Brown, 2004). Thus practicality issues should be considered while designing and conducting a test.

\subsubsection{Authenticity}

Authenticity is an idea that is complex in nature and is not easy to describe, mainly in the dexterity of a test's designing and assessing. Bachman \& Palmer (1996) declare authenticity to be the degree of correlation of the 
features of task of given language test to the characteristics of task of a target language. Therefore, while testing the learners' language skills teachers should try to use the material that is authentic.

\subsubsection{Communication Competence}

Different researchers defined the term communication competence in different ways. There are various definitions of communication competence. The phrase communicative competence is the combination of two terms which represents proficiency to converse (Bagaric \& Djigunovic, 2007). As it displays the ability of a learner to exploit language for successful communication, Canale \& Swain (1980) declares communication competence to be the combination of basic organization of facts and required proficiency for interaction. They comprised communicative competence into the following areas:

- Words and their rules

- Cohesion and coherence

- Appropriateness

- Application of communication approaches

\subsubsection{Grammatical Competence}

It concentrates on a learner's mastery on understanding of sentence formation rules, pronunciation, meanings and spelling (Gao, 2001). It aims to get awareness of, and capability to use, ways of expressing grammatically accurate ideas. Therefore, grammatical competence helps the SLL to use the language accurately and fluently. According to Larsen-Freeman (2001), meaning, form and use are the grammatical aspects that should be stressed, as teaching simply the grammar rules to the learners not assist the learners achieve grammatical competence.

\subsubsection{Sociolinguistic Competence}

It refers to the knowledge about the way of speaking and responding to a language in a particular setting. Sociolinguistic Competence is the learner's competence in choosing the words suitable for that setting, expression of their particular behavior and the knowledge of others behavior. SLLs must have the knowledge of using and understanding the language according to the sociolinguistic contexts, considering the aspects such as communication goals, rules of communication and the participants' status (Freeman \& Freeman, 2004). Learners should be given the chance to practice the language. All the students are needed to participate in language practice during the class. Teacher can help the learners to use suitable meanings and forms during classroom interaction. The meaningful language practices will promote sociolinguistic competence as meaningless content hinders learning (Freeman \& Freeman, 2001).

\subsubsection{Discourse Competence}

Discourse competence is the ability to the knowledge of interpreting the large context and to create language stretches to make it coherent. It is the understanding of arranging and combining the words and sentences to communicate or send messages. It also deals with the visual and written texts. Texts should be clear and apparent. Discourse that is possibly commenced in the classroom might be initiated into the classroom through well-organized methods that engage the learners in culturally congruent ways. The learners often remain silent when the teacher acts like a central executive (Tharp, 1989a). Discourse styles may create difficulty in ESL learning. Cultures differ in conversational styles, turn taking and the ways of sending understandable messages that affects conversation (Diaz-Rico \& Weed, 2010). The learners are required to practice many years at social and academic aspects for achieving this competence level. It is indeed a high goal to achieve.

\section{Research Methodology}

The preferred study was quantitative in nature. This method was chosen because it is easy to find the extent to which an effect occurs. The present research design was descriptive in nature. Descriptive research design was used to discover the ideas and researcher adopted survey based research design. 50 teachers and 100 students of secondary level from government sector were selected to conduct the research. In this study, random sampling and purposive sampling was adopted. The students were selected by using random sampling technique. However, teachers were selected by using purposive sampling technique. Questionnaire is a tool used by a researcher for collecting data. The questions were designed to find the respondents' opinion about washback and its impact and the ways to improve teaching and learning process. Questionnaire used for this study comprises of two parts, first part deals with the demographic information of participants. However, second part comprises 19 items. These items were designed in order to know respondents' perspective about the washback. Test was taken from the students in the classroom. The test was designed to find whether a test affects ESL students' performance or not. The importance of a test in learning second language was also be analyzed. 
Observation checklist was designed in order to observe students' performance in ESL classroom. At first stage students were observed as speaker. However, at next step they were observed as audience. Pilot study was done. The results of the piloted study demonstrated and ensured its content, construct and internal validity. On the other hand, to ensure the reliability of these tools researcher conducted cronbach alpha by using SPSS and researcher found 0.86 reliability ratio of this tool. For this study researcher selected frequency, percentage, means, mode, median and stander deviation formulas. All these formulas were applied by using SPSS.

\section{Data Analysis}

The responses were taken on 05 point likert scale. The data was analyzed through using descriptive statistics technique. The mean value was measured be giving numerical codes to the responses given as under:

Strongly Agree 1

Agree 2

Neutral 3

Disagree $\quad 4$

Strongly Disagree 5

4.1 Interpretation of Data Collected from Questionnaire

The data collected from questionnaire has been analyzed and interpreted as under:

Table 1. Introduction of activities

\begin{tabular}{llllllll}
\hline & & $\begin{array}{l}\text { Strongly } \\
\text { Agree }\end{array}$ & Agree & Neutral & Disagree & $\begin{array}{l}\text { Strongly } \\
\text { Disagree }\end{array}$ \\
\hline Female & Frequency & 10 & 10 & 1 & 2 & 2 & 2.04 \\
& $\%$ & $40 \%$ & $40 \%$ & $4 \%$ & $8 \%$ & $8 \%$ & 3.241 \\
\hline \multirow{2}{*}{ Male } & Frequency & 10 & 8 & 2 & 2 & $3 \%$ & 1.384 \\
& $\%$ & $40 \%$ & $32 \%$ & $8 \%$ & $8 \%$ & $12 \%$ \\
\hline
\end{tabular}

Table 1 displays the results collected from teacher's questionnaire. The data exhibits that majority of members including both male and female were agree with the statement that they would like to introduce activities in my classroom that may help to improve my students' test taking skills.

The mean score of female members are 2.04 and Std. Deviation is 1.241. However, the mean score of male members are 2.20 and Std. Deviation is 1.384 . The overall results interpreted that majority of teachers were of the view that they introduce activities in the classroom which can improve their students test taking skills.

Table 2. Time allotment

\begin{tabular}{llllllll}
\hline & & $\begin{array}{l}\text { Strongly } \\
\text { Agree }\end{array}$ & Agree & Neutral & Disagree & $\begin{array}{l}\text { Strongly } \\
\text { Disagree }\end{array}$ \\
\hline Female & Frequency & 4 & 15 & 3 & 1 & 2 & 2.28 \\
& $\%$ & $16 \%$ & $60 \%$ & $13 \%$ & $4 \%$ & $8 \%$ & 2.061 \\
\hline \multirow{2}{*}{ Male } & Frequency & 11 & 6 & 4 & 2 & 2.120 & $8 \%$ \\
& $\%$ & $44 \%$ & $24 \%$ & $16 \%$ & $8 \%$ & 1.301 \\
\hline
\end{tabular}

Table 2 displays the results collected from teachers' questionnaire. The data shows that majority of female members were agree with the statement that time allotment in classroom will be different incase final exam is cancelled. The mean score of female members are 2.28 and Std. Deviation is 1.301. However, the mean score of male members are 2.120 and Std. Deviation is 1.301 . The overall results interpret that majority of male members as compared to female members were strongly agreed with the statement. 
Table 3. Exams test grammatical competence

\begin{tabular}{|c|c|c|c|c|c|c|c|c|}
\hline & & $\begin{array}{l}\text { Strongly } \\
\text { Agree }\end{array}$ & Agree & Neutral & Disagree & $\begin{array}{l}\text { Strongly } \\
\text { Disagree }\end{array}$ & Mean & Std. D \\
\hline \multirow[t]{2}{*}{ Female } & Frequency & 4 & 11 & 4 & 3 & 3 & 2.60 & 1.258 \\
\hline & $\%$ & $16 \%$ & $44 \%$ & $16 \%$ & $12 \%$ & $12 \%$ & & \\
\hline \multirow[t]{2}{*}{ Male } & Frequency & 6 & 15 & 1 & 2 & 1 & 2.08 & .996 \\
\hline & $\%$ & $24 \%$ & $60 \%$ & $4 \%$ & $8 \%$ & $4 \%$ & & \\
\hline
\end{tabular}

Table 3 depicts the results collected from teacher's questionnaire. The data shows that majority of members were agree with the statement that final exams test the grammatical competence of the students, that is why they spend more time teaching grammatical items. The mean score of female members are 2.60 and Std. Deviation is 1.258. However, the mean score of male members are 2.08 and Std. Deviation is .996. The overall data shows that majority of male members were agree with the statement.

Table 4. Focus final exams objectives

\begin{tabular}{|c|c|c|c|c|c|c|c|c|}
\hline & & $\begin{array}{l}\text { Strongly } \\
\text { Agree }\end{array}$ & Agree & Neutral & Disagree & $\begin{array}{l}\text { Strongly } \\
\text { Disagree }\end{array}$ & Mean & Std. D \\
\hline \multirow[t]{2}{*}{ Female } & Frequency & 5 & 12 & 5 & 2 & 1 & 2.28 & 1.021 \\
\hline & $\%$ & $20 \%$ & $48 \%$ & $20 \%$ & $8 \%$ & $4 \%$ & & \\
\hline \multirow[t]{2}{*}{ Male } & Frequency & 8 & 14 & 1 & 1 & 1 & 1.92 & .953 \\
\hline & $\%$ & $32 \%$ & $56 \%$ & $4 \%$ & $4 \%$ & $4 \%$ & & \\
\hline
\end{tabular}

Table 4 explains the results collected from teacher's questionnaire. The data shows that majority of members including male were agree with the statement that they perform only those activities which fulfill final exams objectives. The mean score of female members are 2.28 and Std. Deviation is 1.021. However, the mean score of male members are 1.92 and Std. Deviation is .953 . To sum up it is stated that majority of male members were agree with the statement.

Table 5. Teach test taking techniques

\begin{tabular}{llllllll}
\hline & & $\begin{array}{l}\text { Strongly } \\
\text { Agree }\end{array}$ & Agree & Neutral & Disagree & $\begin{array}{l}\text { Strongly } \\
\text { Disagree }\end{array}$ \\
\hline Female & Frequency & 9 & 9 & 3 & 2 & 2 & 2.16 \\
& $\%$ & $36 \%$ & $36 \%$ & $12 \%$ & $8 \%$ & $8 \%$ & 1.248 \\
\hline \multirow{2}{*}{ Male } & Frequency & 13 & 8 & 2 & 1 & $4 \%$ & 1.76 \\
& $\%$ & $52 \%$ & $32 \%$ & $8 \%$ & $4 \%$ & $4 \%$ \\
\hline
\end{tabular}

Table 5 exhibits the results collected from teacher's questionnaire. The data shows that majority of members were agree with the statement that "I teach my students 'test taking techniques' especially when final exams dates are announced". The mean score of female members are 2.16 and Std. Deviation is 1.248. However, the mean score of male members are 1.76 and Std. Deviation is 1.052 . To conclude it is stated that majority of female members were agree with the statement.

Table 6. Teaching methodology according to needs

\begin{tabular}{llllllll}
\hline & & $\begin{array}{l}\text { Strongly } \\
\text { Agree }\end{array}$ & Agree & Neutral & Disagree & $\begin{array}{l}\text { Strongly } \\
\text { Disagree }\end{array}$ \\
\hline Female & Frequency & 4 & 8 & 7 & 5 & 1 & 2.64 \\
& $\%$ & $16 \%$ & $32 \%$ & $28 \%$ & $20 \%$ & $4 \%$ & 1.114 \\
\hline \multirow{2}{*}{ Male } & Frequency & 10 & 10 & 3 & 1 & $4 \%$ & 1.92 \\
& $\%$ & $40 \%$ & $40 \%$ & $12 \%$ & $4 \%$ & $4 \%$ \\
\hline
\end{tabular}

Table 6 displays the results collected from teacher's questionnaire. The data shows that majority of members were agree with the statement that I select only those teaching methods which may help my students succeed on final exams. The mean score of female members are 2.64 and Std. Deviation is 1.114. However, the mean score 
of male members are 1.94 and Std. Deviation is 1.038 . To conclude it is stated that majority of male members were that they select pedagogical methods according students' needs. However, vast diversity was found in the opinions taken from female teachers. Their overall responses fall near the response of category of being neutral to the statement, as overall mean value was 2.64 .

Table 7. Preferred skills

\begin{tabular}{|c|c|c|c|c|c|c|c|c|}
\hline & & $\begin{array}{l}\text { Strongly } \\
\text { Agree }\end{array}$ & Agree & Neutral & Disagree & $\begin{array}{l}\text { Strongly } \\
\text { Disagree }\end{array}$ & Mean & Std. D \\
\hline \multirow[t]{2}{*}{ Female } & Frequency & 6 & 9 & 7 & 2 & 1 & 2.32 & 1.069 \\
\hline & $\%$ & $24 \%$ & $36 \%$ & $28 \%$ & $8 \%$ & $4 \%$ & & \\
\hline \multirow[t]{2}{*}{ Male } & Frequency & 11 & 8 & 2 & 2 & 2 & 2.04 & 1.274 \\
\hline & $\%$ & $44 \%$ & $32 \%$ & $8 \%$ & $8 \%$ & $8 \%$ & & \\
\hline
\end{tabular}

Table 7 describes the results collected from teacher's questionnaire. The data shows that majority of members were agreed with the statement that they prefer teaching those skills which are tested on final exams. The mean score of female members are 2.32 and Std. Deviation is 1.069. However, the mean score of male members are 2.04 and Std. Deviation is 1.274. To conclude it is stated that majority of male members were agree with the statement.

Table 8. Avoid using methods that don't support learners

\begin{tabular}{lllllllll}
\hline & & $\begin{array}{l}\text { Strongly } \\
\text { Agree }\end{array}$ & Agree & Neutral & Disagree & $\begin{array}{l}\text { Strongly } \\
\text { Disagree }\end{array}$ & Mean & Std. D \\
\hline Female & Frequency & 4 & 10 & 5 & 4 & 2 & 2.60 & 1.190 \\
& $\%$ & $16 \%$ & $40 \%$ & $20 \%$ & $16 \%$ & $8 \%$ & & 2.240 \\
\hline \multirow{2}{*}{ Male } & Frequency & 7 & 11 & 3 & 2 & 2 & 1.200 \\
& $\%$ & $28 \%$ & $44 \%$ & $12 \%$ & $8 \%$ & $8 \%$ & & \\
\hline
\end{tabular}

Table 8 shows the results collected from teacher's questionnaire. The data shows that majority of members were agree with the statement that they do not use teaching methods that, I think, will not help my students succeed on final exams. The mean score of female members are 2.60 and Std. Deviation is 1.190 . However, the mean score of male members are 2.240 and Std. Deviation is 1.200 . To conclude it is stated that majority of male members were agree with the statement.

Table 9. Influence teaching

\begin{tabular}{llllllll}
\hline & & $\begin{array}{l}\text { Strongly } \\
\text { Agree }\end{array}$ & Agree & Neutral & Disagree & $\begin{array}{l}\text { Strongly } \\
\text { Disagree }\end{array}$ \\
\hline \multirow{2}{*}{ Female } & Frequency & 6 & 13 & 3 & 2 & 1 & 2.16 \\
& $\%$ & $24 \%$ & $52 \%$ & $12 \%$ & $8 \%$ & $4 \%$ & 2 \\
\hline \multirow{2}{*}{ Male } & Frequency & 5 & 12 & 4 & 2 & 2.028 \\
& $\%$ & $20 \%$ & $48 \%$ & $16 \%$ & $8 \%$ & $8 \%$ & 1.150 \\
\hline
\end{tabular}

Table 9 determines respondents' opinions towards the effect and influence of results upon teachers' teaching strategies. The data shows that majority of members were agree with the statement that Final exam has influenced their teaching. The mean score of female members are 2.16 and Std. Deviation is 1.028. However, the mean score of male members are 2.36 and Std. Deviation is 1.150. Overall opinion of the respondents describe that both male and female teachers were agree that results affect their teaching process and teaching strategies. However this tendency was rated a bit higher in female teachers than their male counterparts. 
Table 10. Scarce use of methods which help students

\begin{tabular}{|c|c|c|c|c|c|c|c|c|}
\hline & & $\begin{array}{l}\text { Strongly } \\
\text { Agree }\end{array}$ & Agree & Neutral & Disagree & $\begin{array}{l}\text { Strongly } \\
\text { Disagree }\end{array}$ & Mean & Std. D \\
\hline \multirow{2}{*}{ Female } & Frequency & 5 & 11 & 3 & 5 & 1 & 2.44 & 1.158 \\
\hline & $\%$ & $20 \%$ & $44 \%$ & $12 \%$ & $20 \%$ & $4 \%$ & & \\
\hline \multirow[t]{2}{*}{ Male } & Frequency & 3 & 2 & 2 & 14 & 4 & 3.560 & 1.227 \\
\hline & $\%$ & $12 \%$ & $8 \%$ & $8 \%$ & $56 \%$ & $16 \%$ & & \\
\hline
\end{tabular}

Table shown above explains teachers' practices in English classroom. The data shows that majority of members were agree with the statement that I scarcely use teaching methods which can help my students score good grades. The mean score of female members are 2.44 and Std. Deviation is 1.158 . However, the mean score of male members are 3.560 and Std. Deviation is 1.227 . Overall results indicate that male teachers are not in habit of using innovative teaching methods as compared to female teachers.

Table 11. Extra material to improve test score

\begin{tabular}{lllllllll}
\hline & & $\begin{array}{l}\text { Strongly } \\
\text { Agree }\end{array}$ & Agree & Neutral & Disagree & $\begin{array}{l}\text { Strongly } \\
\text { Disagree }\end{array}$ & Mean & Std. D \\
\hline Female & Frequency & 9 & 11 & 2 & 2 & 1 & 2.00 & 1.080 \\
& $\%$ & $36 \%$ & $44 \%$ & $8 \%$ & $8 \%$ & $4 \%$ & & 1.275 \\
\hline \multirow{2}{*}{ Male } & Frequency & 4 & 10 & 2 & 7 & 2 & 2.720 & \\
& $\%$ & $16 \%$ & $40 \%$ & $8 \%$ & $28 \%$ & $8 \%$ & & \\
\hline
\end{tabular}

Table 11 describes teachers' strategy of introducing extra enrichment material among students. The data shows that majority of members were agree with the statement that "I use extra material in classroom to enhance my students' test score". The mean score of female members are 2.00 and Std. Deviation is 1.080. However, the mean score of male members are 2.720 and Std. Deviation is 1.275. Data shows that female teachers use extensive and extra material in class to provide better understanding to learners. However male teachers though found using extra material often but were rated lower than their female counterparts.

Table 12. Review and memorize expected questions

\begin{tabular}{|c|c|c|c|c|c|c|c|c|}
\hline & & $\begin{array}{l}\text { Strongly } \\
\text { Agree }\end{array}$ & Agree & Neutral & Disagree & $\begin{array}{l}\text { Strongly } \\
\text { Disagree }\end{array}$ & Mean & Std. D \\
\hline \multirow[t]{2}{*}{ Female } & Frequency & 12 & 6 & 3 & 3 & 1 & 2.00 & 1.225 \\
\hline & $\%$ & $48 \%$ & $24 \%$ & $12 \%$ & $12 \%$ & $4 \%$ & & \\
\hline \multirow[t]{2}{*}{ Male } & Frequency & 7 & 12 & 1 & 3 & 2 & 2.24 & 1.234 \\
\hline & $\%$ & $28 \%$ & $48 \%$ & $4 \%$ & $12 \%$ & $8 \%$ & & \\
\hline
\end{tabular}

Table 12 expounds teachers' activities of making students habitual of reviewing and memorization. The data shows that majority of members were agree with the statement that I suggest my students to review and memorize those questions which are expected to be tested on final exams. The mean score of female members are 2.00 and Std. Deviation is 1.225 . However, the mean score of male members are 2.24 and Std. Deviation is 1.234. To conclude it is stated that majority of male and female participants acknowledged the statement.

Table 13. Solving previous papers

\begin{tabular}{llllllll}
\hline & & $\begin{array}{l}\text { Strongly } \\
\text { Agree }\end{array}$ & Agree & Neutral & Disagree & $\begin{array}{l}\text { Strongly } \\
\text { Disagree }\end{array}$ \\
\hline \multirow{2}{*}{ Female } & Frequency & 8 & 12 & 3 & 1 & 1 & 2.00 \\
& $\%$ & $32 \%$ & $48 \%$ & $12 \%$ & $8 \%$ & $8 \%$ & 2 \\
\hline \multirow{2}{*}{ Male } & Frequency & 10 & 9 & 2 & 2 & 2.000 \\
& $\%$ & $40 \%$ & $36 \%$ & $8 \%$ & $8 \%$ & $8 \%$ & 1.256 \\
\hline
\end{tabular}


Table shown above is about respondents' opinions regarding solving previous question papers. The data shows that majority of members were agree with the statement that they suggest their students to solve previous final exams papers. The mean score of female members are 2.00 and Std. Deviation is 1.000 . However, the mean score of male members are 2.080 and Std. Deviation is 1.256 . To conclude it is stated that majority of male and female members were found agree with the statement.

Table 14. Supplementary material

\begin{tabular}{|c|c|c|c|c|c|c|c|c|}
\hline & & $\begin{array}{l}\text { Strongly } \\
\text { Agree }\end{array}$ & Agree & Neutral & Disagree & $\begin{array}{l}\text { Strongly } \\
\text { Disagree }\end{array}$ & Mean & $\overline{\text { Std. D }}$ \\
\hline \multirow[t]{2}{*}{ Female } & Frequency & 5 & 7 & 9 & 2 & 2 & 2.56 & 1.158 \\
\hline & $\%$ & $20 \%$ & $28 \%$ & $36 \%$ & $8 \%$ & $8 \%$ & & \\
\hline \multirow[t]{2}{*}{ Male } & Frequency & 9 & 8 & 2 & 3 & 3 & 2.320 & 1.406 \\
\hline & $\%$ & $36 \%$ & $32 \%$ & $8 \%$ & $12 \%$ & $12 \%$ & & \\
\hline
\end{tabular}

Table 14 demonstrates the teaching practices of participants regarding supplementary material. The data shows that majority of members were agree with the statement that they prefer to use the supplementary material that may help my students succeed on final exams. The mean score of female members are 2.56 and Std. Deviation is 1.158. However, the mean score of male members are 2.320 and Std. Deviation is 1.406. It is clear from the overall mean value that male teachers comparatively use supplementary material more frequently than female teachers.

Table 15. Excluding less important chapters from exams point of view

\begin{tabular}{|c|c|c|c|c|c|c|c|c|}
\hline & & $\begin{array}{l}\text { Strongly } \\
\text { Agree }\end{array}$ & Agree & Neutral & Disagree & $\begin{array}{l}\text { Strongly } \\
\text { Disagree }\end{array}$ & Mean & Std. D \\
\hline \multirow[t]{2}{*}{ Female } & Frequency & 3 & 6 & 7 & 7 & 2 & 2.96 & 1.172 \\
\hline & $\%$ & $12 \%$ & $24 \%$ & $28 \%$ & $28 \%$ & $8 \%$ & & \\
\hline \multirow[t]{2}{*}{ Male } & Frequency & 9 & 9 & 3 & 3 & 1 & 2.120 & 1.166 \\
\hline & $\%$ & $36 \%$ & $36 \%$ & $12 \%$ & $12 \%$ & $4 \%$ & & \\
\hline
\end{tabular}

Table 15 explored teachers' habits of excluding less important syllabus from teaching and learning process. The data shows that majority of members were agree with the statement that they do not teach chapters which are not important from final exams point of view. The mean score of female members are 2.96 and Std. Deviation is 1.172. However, the mean score of male members are 2.120 and Std. Deviation is 1.166. It was interesting to find that male teachers are more habitual of excluding less important chapters in their teaching.

Table 16. Final exams influence teaching

\begin{tabular}{llllllll}
\hline & & $\begin{array}{l}\text { Strongly } \\
\text { Agree }\end{array}$ & Agree & Neutral & Disagree & $\begin{array}{c}\text { Strongly } \\
\text { Disagree }\end{array}$ \\
\hline \multirow{2}{*}{ Female } & Frequency & 7 & 12 & 2 & 2 & 2 & 2.20 \\
& $\%$ & $28 \%$ & $48 \%$ & $8 \%$ & $8 \%$ & $8 \%$ & 1.190 \\
\hline \multirow{2}{*}{ Male } & Frequency & 9 & 13 & 1 & 1 & $4 \%$ & .971 \\
& $\%$ & $36 \%$ & $52 \%$ & $4 \%$ & $4 \%$ & & $4 \%$ \\
\hline
\end{tabular}

Table 16 explains teaching practices and habits near final exams of English language learners. The data shows that majority of members were agree with the statement that their sequence of teaching objectives is influenced by final exams. The mean score of female members are 2.20 and Std. Deviation is 1.190 . However, the mean score of male members are 1.880 and Std. Deviation is .971. To conclude both male and female teachers opined that their teaching objectives are very much influenced by the repercussions of final exams. 
Table 17. Include content which help students

\begin{tabular}{|c|c|c|c|c|c|c|c|c|}
\hline & & $\begin{array}{l}\text { Strongly } \\
\text { Agree }\end{array}$ & Agree & Neutral & Disagree & $\begin{array}{l}\text { Strongly } \\
\text { Disagree }\end{array}$ & Mean & Std. D \\
\hline \multirow[t]{2}{*}{ Female } & Frequency & 7 & 12 & 4 & 1 & 1 & 2.08 & .997 \\
\hline & $\%$ & $28 \%$ & $48 \%$ & $16 \%$ & $4 \%$ & $4 \%$ & & \\
\hline \multirow[t]{2}{*}{ Male } & Frequency & 5 & 15 & 3 & 1 & 1 & 2.120 & .927 \\
\hline & $\%$ & $20 \%$ & $60 \%$ & $12 \%$ & $4 \%$ & $4 \%$ & & \\
\hline
\end{tabular}

Table 17 illustrates the examination preparation stage of English language learners. The data shows that majority of members were agree with the statement that I include all the relevant content which can help my students succeed on final exams. The mean score of female members are 2.08 and Std. Deviation is .997. However, the mean score of male members are 2.120 and Std. Deviation is $.927 .28 \%$ female teachers were strongly agree and $48 \%$ of them were found agree with the statement. Similarly, $20 \%$ male teachers were strongly agree and $60 \%$ were opined as agree with the above statement. The mean value demonstrates that majority of the respondents of both genders include all relevant materials and contents at exams preparation stage.

Table 18. Introducing exams' objectives

\begin{tabular}{|c|c|c|c|c|c|c|c|c|}
\hline & & $\begin{array}{l}\text { Strongly } \\
\text { Agree }\end{array}$ & Agree & Neutral & Disagree & $\begin{array}{l}\text { Strongly } \\
\text { Disagree }\end{array}$ & Mean & Std. D \\
\hline \multirow[t]{2}{*}{ Female } & Frequency & 8 & 9 & 5 & 1 & 2 & 2.20 & 1.190 \\
\hline & $\%$ & $32 \%$ & $36 \%$ & $20 \%$ & $4 \%$ & $8 \%$ & & \\
\hline \multirow[t]{2}{*}{ Male } & Frequency & 13 & 8 & 2 & 1 & 1 & 1.76 & 1.052 \\
\hline & $\%$ & $52 \%$ & $32 \%$ & $8 \%$ & $4 \%$ & $4 \%$ & & \\
\hline
\end{tabular}

Table 18 describes teachers' tendency of targeting final exams objectives during the whole term. The data shows that majority of members were agree with the statement that the objectives of final exams are clearly displayed in their course content. The mean score of female members are 2.20 and Std. Deviation is 1.190. However, the mean score of male members are 1.76 and Std. Deviation is $1.052 .32 \%$ female respondents were strongly agree with the statement while $36 \%$ were found agree with it. On the other hand, the percentage was quite higher in male teachers where $52 \%$ were found strongly agree and $32 \%$ were found agree. It is concluded that male teachers focus more on displaying course objectives in their course contents than their female counterparts.

Table 19. Teaching and testing whole syllabus

\begin{tabular}{|c|c|c|c|c|c|c|c|c|}
\hline & & $\begin{array}{l}\text { Strongly } \\
\text { Agree }\end{array}$ & Agree & Neutral & Disagree & $\begin{array}{l}\text { Strongly } \\
\text { Disagree }\end{array}$ & Mean & Std. D \\
\hline \multirow[t]{2}{*}{ Female } & Frequency & 7 & 5 & 5 & 7 & 1 & 2.60 & 1.291 \\
\hline & $\%$ & $28 \%$ & $20 \%$ & $20 \%$ & $28 \%$ & $8 \%$ & & \\
\hline \multirow[t]{2}{*}{ Male } & Frequency & 2 & 3 & 2 & 15 & 3 & 3.56 & 1.121 \\
\hline & $\%$ & $8 \%$ & $12 \%$ & $8 \%$ & $60 \%$ & $12 \%$ & & \\
\hline
\end{tabular}

The data shows that majority of members were agree with the statement that I cover every chapter of the text book though some of the chapters may not be tested on final exams. The mean score of female members are 2.60 and Std. Deviation is 1.291. However, the mean score of male members are 3.56 and Std. Deviation is 1.121. To conclude it is stated that majority of female members were agree with the statement, however male members were disagree with the statement.

\subsection{Interpretation of Data Collected from Speaking Proficiency Test}

A test was also conducted to check the learners' level of competence. The data shows the numerical scores which were used for each category to derive a final score for the assessment.

- The data displays the statistics about the pronunciation test score of both male and female students. The data interpreted that the mean score is 2.66 for male and 2.96 for female. Additionally, median and mode is 3.00 for both male and female and the Std. deviation is .51942 male and .75485 female. Additionally, majority of members were at beginning level including $60 \%$ male and $48 \%$ female, some 
of them were at emerging including $35.3 \%$ male and $29.4 \%$ female. However, only few were at intermediate level.

- The data construed that the mean score in fluency test for male is 2.58 and for female is 2.88 . Additionally, median and mode is 3.00 for both male and female and the Std. deviation is .49857 male and .74715 female. Moreover, majority of members were at beginning level including $56 \%$ male and $43 \%$ female, some of them were at emerging level including $43.2 \%$ male and $33.3 \%$ females. However, only few were at intermediate level.

- The data further demonstrates the statistical interpretation about the comprehension test score of students. The data interpreted as that the mean score is 2.52 male and 3.0 female. Additionally, median and mode is 3.00 for both male and female and the Std. deviation is .50467 male and .80812 female. Moreover, majority of members were at beginning level including $51 \%$ male and $35 \%$ females, some of them were at emerging $47 \%$ male and $31 \%$ females. However, only few were at intermediate level.

- The content test results display that the mean score is 2.34 male and 2.66 female. Additionally, median is 2.0 for male and female and mode is 2.00 for both male and female and the Std. deviation is .47852 male and .71742 female Furthermore, majority of members were at emerging level including $65 \%$ male $47 \%$ female, some of them were at beginning level including $33.3 \%$ male and $35.5 \%$ females. However, only few were at intermediate level.

- The data about vocabulary test shows that the mean score is 2.42 male and 2.78 female. Median and mode is same for both male and female which is 2.00 male and 3.00 female. Moreover, Std. deviation is .49857 male and .67883 female. Additionally, majority of female members including $49 \%$ were at beginning level, some of the male members including $56.9 \%$ were at emerging and only few were at intermediate level.

\subsection{Interpretation of Data Collected from Observation Checklist}

To conduct this study twenty classrooms were observed by the researchers in order to find out the learners' performance in classrooms as well.

- The data shows that majority of students used appropriate voice while presenting in front of class.

- However, only few of them used complete sentences in their conversation.

- The data also highlights that only few of them maintained topic in the oral communication.

- Majority of members speak fluently and talks for an appropriate length of time.

- Yet, some of the members were unable to respond to the audience on request.

- The data also revealed that majority of members were unable to speak at a reasonable pace.

- Some of them were able to verbalize everything that is presented visually.

- Majority of member stresses most important points by pausing, speaking slowly, raising voice, etc. to some extent.

- The data also revealed that some of them speak in a dramatic or expressive way, tells jokes or humorous anecdotes.

- When students were observed as audience then students showed better results they listen attentively and ask questions or offers comments. Moreover, they take turns during discussion.

\section{Conclusion}

Many studies were conducted in order to find out the effect of washback on learners' performance. Recent study is an attempt to find the extent of positive and negative washback that influence learners' performance. Moreover, researcher also investigated the role of teachers in teaching and learning second language. The findings of the study show that the testing effect on learning and teaching has been connected with consequential validity of a test. The findings of the study reveal that majority of teachers were agree with the statement that time allocated in the classroom was not sufficient to teach the subject matter to students. Teachers also claimed that if more time was given to them they can teach students according to their needs by practicing latest teaching methods. Moreover, their teachings were based on fulfilling the objectives of the exams rather than fulfilling the needs of learners. It is also observed that those teachers who have done their master in linguistics made conscious efforts to improve their students' communication skills. This study also reveals that grammar translation method is still being used in classrooms. Teachers normally focus writing and reading skills and pay 
less attention towards speaking or listening skills. Teachers teach only those lessons and contents which they consider useful according to exams point of view. The findings of the study show that majority of teachers claimed that washback influence and affect their selection of teaching methods because exams create pressure on them and it becomes necessary for English teachers to develop linguistic competence among their students.

\section{Recommendations}

For future researches it is recommended that other studies should be made in order find out the impact of washback on the strategies adopted by learners while learning second language. Another study can be conducted to know the role of washback while learning English language as a second language. Furthermore, recent study is limited only to secondary level. However, other studies can be conducted at college or university level. Last but not least, this study is limited only to Punjab province however other studies should be conducted in different demographic areas of other provines as well.

\section{References}

Al Hosni, S. (2014, June). Speaking Difficulties Encountered by Young EFL Learners. International Journal on Studies in English Language and Literature (IJSELL), 2(6), 22-30.

Alderson, J. C., \& Hamp-Lyons, L. (1996). TOEFL preparation courses: a study of washback. Language Testing, 13(3), 280-297. https://doi.org/10.1177/026553229601300304

Alderson, J. C., \& Wall, D. (1993). Does washback exist? Applied Linguistics, 14(2), 115-129. https://doi.org/10.1093/applin/14.2.115

Bachmann L., \& Palmer, A. (1996). Language Testing in Practice. Oxford: Oxford University Press. Retrieved from http://www.goodreads.com/book/show/1605674.Language-Testing-in-Practice

Bagaric, V., \& Djigunovic, J. M. (2007). Defined Communicative Competence. Metodika, 8, 94-103.

Baniabdelrahman, A. A. (2013). Effect of Using Internet Tools on Enhancing EFL Students' Speaking Skill. American International Journal of Contemporary Research, 3(6), 80-81.

Bashir, M., Azeem, M., \& Dogar, A. H. (2011). Factor Effecting Students' English Speaking Skills. British Journal of Arts and Social Sciences, 2(1), 38-40, 48.

Bilal, H. A., Rehman, A., Rashid, C. A., Adnan, R., \& Abbas, M. (2013). Problems in speaking English with L2 Learners of Rural Area Schools of Pakistan. European Journal of Humanities and Social Sciences, 24(1), $34-40$.

Brown. (2004). Language Assessment: Principles and Classroom Practices. Longman publishers.

Buck, G. (1988). Testing listening comprehension in Japanese university entrance examinations. JALT, (10).

Canale, M., \& Swain, M. (1980). Theoretical bases of communicative approaches to second language teaching and testing. Applied Linguistics, 1, 1-47. https://doi.org/10.1093/applin/1.1.1

Cheng, L. (2001). Washback studies: methodological considerations. Curriculum Forum, 10(2), 7-32.

Cheng, L. (2004). The washback effect of a public examination change on teachers' perceptions toward their classroom teaching. In L. Cheng, Y. Watanabe, \& A. Curtis (Eds.), Washback in language testing: Research contexts and methods (pp. 147-170). Mahwah, New Jersey: Lawrence Erlbaum Associates, Publishers.

Cheng, L., Sun, Y., \& Ma, J. (2015). Review of washback research literature within Kane's argument-based validation framework. Language Teaching, 48, 436-470. https://doi.org/10.1017/S0261444815000233

Davies, A. (1985). Follow my leader: Is that what language tests do? In Y. P. Lee, C. Y. Y. Fok, R. Lord, \& G. Low (Eds.), New directions in language testing (pp. 1-12). Oxford: Pergamon Press.

Diaz-Rico, L. T., \& Weed, K. Z. (2010). The crosscultural, language, and academic handbook. Boston, MA: Allyn \& Bacon.

Freeman, D. E., \& Freeman, Y. S. (2001). Between Worlds Access to Second Language Acquististion. Portsmouth, NH: Heinemann.

Freeman, D. E., \& Freeman, Y. S. (2004). Essential linguistics: What you need to know to teach reading, ESL, spelling, phonics, and grammar. Portsmouth, $\mathrm{NH}$ : Heinemann.

Gao, C. Z. (2001). Second language learning and the teaching of grammar. Education, 2, 326-336

Gass, S. M., \& Selinker, M. (Ed.). (2008). Second Language Acquisition. New York \& UK: Routledge. 
Kelley, T. L. (1927). Interpretation of educational measurements. New York: Macmillan.

Larsen-Freeman, D. (2001). Teaching grammar. In M. Celce-Murcia (Ed.), Teaching English as a second or foreign language (pp. 251-266). Boston, MA: Heinle \& Heinle.

Lee, C. K. (2010). An overview of language learning strategies. Arecls, 7, 132-152.

Madrid, D. (1995). Internal and external factors in language teaching. Actas de las 1I Jornadas de Estudios Ingleses. Universidad de Jaen, 2(2), 59-82.

Madsa, T. (2012). Motivating Students' Speaking Skill Through Simulation in English for Specific Purposes. 1st Mae Fah Luang University International Conference, Thailand, 3-6.

McEwen, N. (1995). Educational accountability in Alberta. Canadian Journal of Education, 20(1), 27-44. https://doi.org/10.2307/1495050

McMillan, J. H. (2001). Classroom assessment: Principles and practice for effective instruction (2nd ed.). Boston: MA: Allyn \& Bacon.

McNamara, T. (2000). Language Testing. Oxford: Oxford University Press.

Mehrpour, S., \& Vojdani, M. (2012). Globalization and EFL Learning Motivation: A New Perspective on Integrative vs. Instrumental Motivation among Iranian Learners of English. Blackwell Publishing House.

Messick, S. (1996). Validity and washback in language testing. Language Testing, 13(4), 241-256. https://doi.org/10.1177/026553229601300302

Morrow, K. (1986). The evaluation of tests of communicative performance. In M. Portal (Ed.), Innovations in language testing. London: NFER/ Nelson.

Prodromou, L. (1995). The Backwash Effect: from Testing to Teaching. Language Testing, 49(1), 13-25. https://doi.org/10.1093/elt/49.1.13

Rodr1'guez-Muñiz, L. J., Di'az, P., Mier, V., \& Alonso, P. (2016). Washback Effect of University Entrance exams in Applied Mathematics to Social Sciences. Plos One, 11(12), e0167544. https://doi.org/10.1371/journal.pone.0167544

Shohamy, E. (1992). Beyond proficiency testing: A diagnostic feedback testing model for assessing foreign $\begin{array}{llll}\text { language learning. Modern } & \text { Language Journal, }\end{array}$ https://doi.org/10.1111/j.1540-4781.1992.tb05402.x

Tharp, R. G. (1989). Psycho cultural variables and constants: Effects on teaching and learning in schools. American Psychologist, 44(2), 349-359. https://doi.org/10.1037/0003-066X.44.2.349

\section{Copyrights}

Copyright for this article is retained by the author, with first publication rights granted to the journal.

This is an open-access article distributed under the terms and conditions of the Creative Commons Attribution license (http://creativecommons.org/licenses/by/4.0/). 